\title{
15. SEDIMENTARY RHYTHMS AND CLIMATIC FORCING OF PLEISTOCENE-HOLOCENE MIXED CARBONATE/SILICICLASTIC SEDIMENTS OFF THE GREAT BARRIER REEF ${ }^{1}$
}

\author{
Craig R. Glenn, ${ }^{2}$ Dick Kroon, ${ }^{3}$ and Wuchang Wei ${ }^{4}$
}

\begin{abstract}
Sediments recovered from the upper-slope and outer-shelf Great Barrier Reef transect (Ocean Drilling Program Leg 133, Sites 819 through 821 ) contain a high-resolution, 1.5-m.y. record of mixed siliciclastic and carbonate sedimentation. More than 30 multimeter-scale couplets of fining- and coarsening-upward sediments having varying proportions of carbonate and authigenic glauconite are present. These couplets stack into cyclic bundles observed in carbonate and magnetic susceptibility data that, in turn, vary systematically with respect to systems tract development deduced from sequence-stratigraphic analysis. At Site 821 , these bundles and their variations clearly track relative changes in sea level for the past $\sim 1.48 \mathrm{~m}$.y. The data presented suggest that these various levels of cyclicity are expressed as the result of high sedimentation rates along the margin and that the dominant control on their development has been climate variations that modulated variations in sea level and terrigenous influx. The average duration of many of these cycles is in the Milankovitch waveband and is related to both fourth- (102-443 ka) and fifth-order (34-88 ka) cycles of sea-level change. These cycles are examined with respect to their lithology (color, percentage of total foraminifers, bioclasts, siliciclastics, authigenic glauconite, nannofossils, and tunicates), sequence stratigraphy, downhole log characteristics, magnetic susceptibility, and percentage of carbonate. Time series and Fourier transform results from high-resolution magnetic susceptibility and sonic velocity data suggest strong orbital forcing of the sedimentary cycles, although with differing intensities for different depositional packages and time frames. Magnetic susceptibility/carbonate cycles are interpreted as pulses of deposition of fine-grained siliciclastics during times of maximum flooding (along downlapped surfaces) and subsequent highstand progradation. These pulses dilute carbonate and contain fine-grained magnetically susceptible detrital minerals.
\end{abstract}

\section{INTRODUCTION}

Throughout the past 2 m.y. (cf. Hays et al., 1976), and probably during much of the Phanerozoic record at least (e.g., Berger et al., 1984; Einsele et al., 1991; Fischer and Bottjer, 1992), the major mechanism for changing global climate on time scales between 10,000 and $500,000 \mathrm{yr}$ appears to have been changes in the distribution of solar energy by latitude and by season, as dictated by three master orbital variables. These are 41-k.y. obliquity cycles of changes in the inclination (tilt) of the Earth's rotational axis, 100- and 413-k.y. eccentricity cycles of the changing shape of the Earth's orbit around the sun (from circular to more elliptical), and 19- and 23-k.y. precession cycles. The last-mentioned are related to changing distance between the Earth and the sun at any given season and are modulated by the waxing and waning of the cycles of eccentricity. The effects of all orders of orbital forcing now have been well documented in the deep-marine record (cf. Imbrie et al., 1984, 1989) and in terrestrial records as well (cf. Glenn and Kelts, 1991, for summary).

This study analyzes the nature of cyclic marine sedimentation recovered from the Great Barrier Reef (GBR) transect of Ocean Drilling Program (ODP) Leg 133 (Sites 819 through 821). For our purposes, the cycles and rhythms discussed here have been grouped into packages representing particular orders of duration (Table 1). Our approach is similar to that of Roof et al. (1991) for the Gulf of Mexico (Site 625) in that we attempt to analyze data collected not from the deep sea but, rather, from a relatively shallow-water, mixed carbonate/siliciclastic depositional setting lying adjacent to a passive continental margin. Our data set differs significantly from Roof et al.'s and other data sets, however, in that we are analyzing sedimentary cyclic-

${ }^{1}$ McKenzie, J.A., Davies, P.J., Palmer-Julson, A., et al., 1993. Proc. ODP, Sci. Results, 133: College Station, TX (Ocean Drilling Program).

${ }^{2}$ Department of Geology and Geophysics, School of Ocean and Earth Science and Technology, University of Hawaii, Honolulu, HI 96822, U.S.A.

${ }^{3}$ Department of Geology and Geophysics, University of Edinburgh, Edinburgh, EH9 3JW, United Kingdom.

${ }^{4}$ Scripps Institution of Oceanography, La Jolla, CA, 92093, U.S.A. ity from a section that was deposited at very high rates ( $>1000 \mathrm{~m} / \mathrm{m} . \mathrm{y}$.) and contains a complicated, mixed assemblage of both open-marine and shallow-water-dwelling organisms, sand- to clay-sized siliciclastic materials, fining- and coarsening-upward cycles, and authigenic mineral phases.

Here, we document and interpret the cyclicity present in seismic, sedimentologic, geochemical, magnetic, and downhole-logging data in terms of their causal mechanisms. These cycles are examined with respect to their lithology (color, percentage of total foraminifers, bioclasts, siliciclastics, authigenic glauconite, nannofossils, and tunicates), sequence stratigraphy, downhole log characteristics, magnetic susceptibility, and carbonate content. We first describe the general nature of the cycles and then apply statistical approaches to the high-resolution portions of the data set to examine their underlying periodicities. Variations of climate at low latitudes, such as off the northern GBR, are thought to be dominated by eccentricity and precessional cycles. This is due to both the diminished effect of obliquity changes and the increased importance of monsoons at low latitudes. Through regulation of the heating intensity of continental masses, orbital precession influences rates of precipitation on 19- and 23-k.y. periods by altering the intensity of low-pressure cells that drive monsoonal winds (Rossignol-Strict, 1983; Pokras and Mix, 1985; Prell and Van Campo, 1986; Prell and Kutzbach, 1987). This precessional control on low-latitude precipitation is modulated by the eccentricity cycle. As outlined below, however, our data suggest that evidence for eccentricity, precession, and obliquity cycles is present in the GBR cores and that forcing by all of these orbital rhythms impacts sedimentation primarily by influencing rates and magnitude of sea-level change and, secondarily, by modulating relative rates of terrigenous influx.

\section{METHODS}

Sedimentary cycles in cores from Sites 819 and 821 were defined by the following parameters: variations in core color; percentage total carbonate; percentage $>63-\mu \mathrm{m}$ fraction of glauconite, siliciclastics, and nonforaminifer bioclasts; percentage total foraminifers; percent- 
Table 1. Duration of sequence stratigraphic cycles (after Vail et al., 1991; Wornardt and Vail, 1991), orbital cycles, and seismic sequences present along the Great Barrier Reef, Sites 819-821.

\begin{tabular}{|c|c|c|c|}
\hline Order & $\begin{array}{l}\text { Duration of } \\
\text { seq. strat. } \\
\text { cycle }\end{array}$ & $\begin{array}{l}\text { Orbital } \\
\text { cycle } \\
\text { (period) }\end{array}$ & $\begin{array}{c}819-821 \\
\text { GBR seismic } \\
\text { sequences }\end{array}$ \\
\hline 1 & $50+\mathrm{Ma}$ & & \\
\hline 2 & $3-50 \mathrm{Ma}$ & & \\
\hline 3 & $500 \mathrm{ka}-3 \mathrm{Ma}$ & & \\
\hline 4 & $80 \mathrm{ka}-500 \mathrm{ka}$ & Eccentricity (413 ka, $100 \mathrm{ka})$ & $1,2,3,5,6,7,8$ \\
\hline 5 & $30 \mathrm{ka}-80 \mathrm{ka}$ & Obliquity (41 ka) & $4,6 \mathrm{~A}, 6 \mathrm{~B}, 6 \mathrm{C}$ \\
\hline 6 & $10 \mathrm{ka}-30 \mathrm{ka}$ & Precession (19 ka, $23 \mathrm{ka})$ & \\
\hline
\end{tabular}

age total nannofossils; percentage total tunicates; magnetic susceptibility; and downhole variations in velocity, resistivity, and gamma-ray production (also see Glenn et al., this volume). Total carbonate and carbon contents were determined by acidification and furnace-tied coulometric titration, respectively (cf. Huffman, 1977; Engleman et al., 1985). Total carbonate concentrations reported here represent a combined data set of shipboard and shore-based results. Preliminary shipboard nannofossil determinations were augmented with examination of samples spaced approximately every $1.5 \mathrm{~m}$ in the recovered cores. Nannofossil smear slides were made from unprocessed sediments. Magnetic susceptibility (core-log) and downhole wireline sonic velocity and gamma-ray log data discussed here were collected during shipboard operations. Magnetic susceptibility and downhole logging measurements were taken about every 10 to $15 \mathrm{~cm}$ downcore, respectively. Most logging tools have a vertical resolution of about $50 \mathrm{~cm}$. Combined with the high sedimentation rates encountered at Sites 819 through 821 (see below), these measurements thus provide for a near-continuous record of variations in these properties, with a vertical resolution of slightly better than $1000 \mathrm{yr}$. Magnetic susceptibility is the ratio of induced magnetization to an applied weak magnetic field and is proportional to magnetic mineral concentration, which is usually a trace component of the terrigenous fraction. Because of the high sample density obtained in its measurement, magnetic susceptibility measurement can thus provide a sensitive, high-resolution record of variations in terrigenous sedimentation in pelagic or carbonate-dominated settings (e.g., Kent, 1982; Mead et al., 1986; Robinson, 1986; Bloemendal et al., 1988; Doh et al., 1988; Bloemendal and deMenocal, 1989). Interpretations of the sequence stratigraphy between Sites 819 and 821 are discussed in detail in Glenn et al. (this volume).

\section{Statistical Methods}

The data obtained from Sites 819 through 821 represent a compound signal of cyclic sedimentation. To examine the periodicity of this sedimentation, a Fourier analysis was completed for variations in magnetic susceptibility from whole-round core segments and for sonic velocity from downhole wireline data. These data sets were used because they were found to show a strong correlation to other cyclic variations observed in the cores and because they contain an essentially uninterrupted, very high-resolution record of these cycles. The spectral analysis procedures (e.g., Jenkins and Watts, 1968; Davis, 1986) were incorporated into a personal computer program (IGOR) that first converts the depth scale to a time scale using a linear interpolation between the biostratigraphic control points and removing larger-scale "background" trends (such as the progressive increase in velocity with depth) by fitting and then removing a third-order polynomial regression estimate from the data. The program then computes the raw spectral density estimates using a discrete Fourier transform. When the results of these analyses are plotted, each spectral density plot is normalized relative to the highest power obtained for each window. In this way, within each plot, ratios of spectral
Table 2. Summary of mean depths (mbsf) of biostratigraphic horizons from Sites 819, 820, and 821 .

\begin{tabular}{llrrr}
\hline \multicolumn{1}{c}{ Datum } & $\begin{array}{l}\text { Age } \\
\text { (Ma) }\end{array}$ & $\begin{array}{r}\text { Site } \\
819\end{array}$ & $\begin{array}{r}\text { Site } \\
820\end{array}$ & \multicolumn{1}{c}{$\begin{array}{c}\text { Site } \\
821\end{array}$} \\
\hline LO Emiliania huxleyi acme & 0.08 & 8.4 & 12.1 & \\
LO Emiliania huxleyi & 0.275 & 29.4 & 35.8 & 39.3 \\
HO Psuedoemiliania lacunosa & 0.465 & 32.4 & 107.1 & 123.1 \\
HO Gephyrocapsa spp. C-D & 0.92 & 56.0 & 163.6 & 176.8 \\
HO Gephyrocapsa spp. A-B & 1.10 & 116.87 & 260.3 & 270.1 \\
HO Helicosphaera sellii & 1.27 & 189.2 & 271.7 & 279.2 \\
HO Calcidiscus macintyrei & 1.48 & $>400$ & $>400$ & $>400$ \\
\hline
\end{tabular}

Notes: Biostratigraphic age assignments updated from Berggren et al. (1985). The age scales calculated for these cores assume a constant sedimentation rate between each age datum. $\mathrm{LO}=$ lowest occurrence, $\mathrm{HO}=$ highest occurrence. For more information, see Wei (this volume).

density peak heights can be compared. The program was initially run for overlapping time windows ( 200-k.y. windows with 50-k.y. overlap) and later modified for smaller windows designed to sample specific portions of the data set or for windows that improved the removal of low-amplitude noise. We have restricted these analyses to Site 821 because of the large number of hiatuses and unconformities encountered at Site 819 (cf. Glenn et al., this volume).

\section{RESULTS}

\section{Biostratigraphy and Sedimentation Rates}

Our biostratigraphic results are presented in Table 2. Mean depths of nannofossil datums represent the mean between the position of the highest or lowest occurrence of the indicator species and the position of the next highest or lowest sample in the core not containing the species. Because the highest occurrence of Calcidiscus macintyrei (1.48 Ma) was not found in the base of the recovered cores from Sites 819,820 , or 821 , we have assumed (probably wrongly) that the base of the cores dates to $1.47 \mathrm{Ma}$ for the purposes of interpolating age data through the base of the cores. This assumes that Calcidiscus macintyrei should be present at these sites, likely underestimates the ages at the bottom of the cores, and, thus, underestimates sedimentation rates below the $1.27 \mathrm{Ma}$ datum. This assumption does, however, allow us to attempt to extract data on the periodicity of the cyclicity for the intervals of the cores greater than 1.27 Ma. The significance of this assumption is discussed more fully below.

In Hole $819 \mathrm{~A}$, sedimentation rates are high and variable (Fig. 1) and range from a low value of 15.8 Bubnoffs (millimeters/thousand years $=$ meters/million years) associated with an unconformity (at the sequence boundary separating seismic Sequences 2 and 5; Fig. 2) to $>1054$ Bubnoffs below 189 mbsf. These sedimentation rates are high relative to most hemipelagic depositional settings but are comparable to those typical of many highly productive reef and carbonate periplatform environments (cf. Enos, 1991). In Hole 821A, sedimentation rates vary from a low of 53 Bubnoffs, associated with an unconformity at the sequence boundary separating seismic Sequences 7 and 8 , to a high of $>575$ Bubnoffs for Sequences 8 and 9 at the base of the core (Figs. 1 and 3 ).

\section{Upward-Coarsening and -Fining Cycles}

Subtle rhythmic couplets of strata are identifiable throughout the recovered GBR section, but with decreasing resolution with increasing age. At Site 819 more than 30 rhythmic couplets are identified by a general coarsening upward from clay-rich, dark greenish-gray oozes through relatively carbonate-rich, commonly bioclastic greenish-gray oozes to wackestones (Figs. 2 and 4). Carbonate concentrations, magnetic susceptibilities, and wireline logs generally track the rhythmicity of these sedimentation couplets, and all were used as aids for refining 
the positions and transitions of these cycles downhole. Throughout Site 819 , the upward-coarsening sequences of these cycles are characterized by dark green oozes subtly passing upward into lighter green oozes/wackestones, which reflect upward-decreasing proportions of siliciclastic muds and increasing proportions of relatively shallowwater, bioclastic detritus. The basal clay, quartz, and feldspar-rich half-couplets of each cycle may relate to enhanced terrigenous influx during relative decreases in sea level. The coarser upper portion of each cycle corresponds to relative increases in sea level when neritic carbonate production was a maximum and its detritus was shed toward the basin. This interpretation is in keeping with recent studies that relate increases in carbonate production and basin filling during interglacial episodes (cf. Droxler and Schlager, 1985; Boardman et al., 1986) but is unlike that for coarsening-upward sequences typifying many shoaling terrigenous-dominated settings (e.g., prograding wave-dominated clastic shorelines or interregional fluviodeltaic systems). In contrast, the sedimentary rhythms developed in the more proximal setting of Site 821 are dominated by a mixture of finingand coarsening-upward units (Fig. 3). Units that fine upward tend to dominate the upper half of the hole $(\sim 0-0.92 \mathrm{Ma})$, while coarseningupward cycles are more common in the recovered interval below this. This upsection change from packages of coarsening-upward to fining-upward cyclic sedimentation corresponds to (1) a major change in the overall seismic architecture of the margin, from a lower progradational bias to an upper aggradational bias (cf. Glenn et al., and Davies et al., both this volume), (2) a change from a fully marine to a mixed terrigenous/marine source of sedimentary organic matter (Shipboard Scientific Party, 1991), (3) a marked increase in percentage of bioclasts in the upper portion of the hole (Fig. 3), and (4) a marked decrease in the persistence and frequency of nannofossils (Fig. 3). Interestingly, percentages of shallow-water tunicates (cf. Wei, this volume) and total foraminifers transcend this boundary with little variation (Fig. 3).

\section{Cyclic Bundling of Magnetic Susceptibility and Calcium Carbonate}

At both Sites 819 and 821 , calcium carbonate and magnetic susceptibility variations mirror each other in that decreases in calcium carbonate precisely correlate with increases in magnetic susceptibility (Figs. 2 and 3). This covariance results in a rhythmic bundling of these two components when plotted vs. each other downcore or in cross plots. Figure 5 illustrates that, with few exceptions, the covariance between calcium carbonate and magnetic susceptibility is linear and negative and, further, that reduction diagenesis has not affected these data. Figure 6 depicts this relationship and illustrates how the two sites relate to each other with respect to nannofossil datums, major hiatuses and unconformities, and sequence-stratigraphic architecture at each site. The bundling record at the more distal slope Site 819 is more jagged than at Site 821 and has been punctuated with a number of unconformities and slump surfaces (see Glenn et al., this volume). At Site 821 , where the record is most complete, the bundles often occur as rhythmic alternations between large bundles (relatively high magnetic susceptibility, low carbonate) and smaller bundles (relatively low magnetic susceptibility, high carbonate). In many cases, these large and small bundles tend to form couplets roughly corresponding to the transgressive and highstand systems tracts identified from sequence-stratigraphic analysis (Figs. 4 and 6; Glenn et al., this volume). There is also an upsection trend for increasing carbonate maxima and decreasing magnetic susceptibility minima from 400 to $123 \mathrm{mbsf}$, and decreasing carbonate maxima and slightly increasing magnetic susceptibility minima from 123 to $0 \mathrm{mbsf}$. This changeover at $123 \mathrm{mbsf}$ corresponds to a remarkable maximum pinching of the bundles in seismic Sequence 5 and approximately corresponds to a rapid mid-Pleistocene climate mode change toward more severe
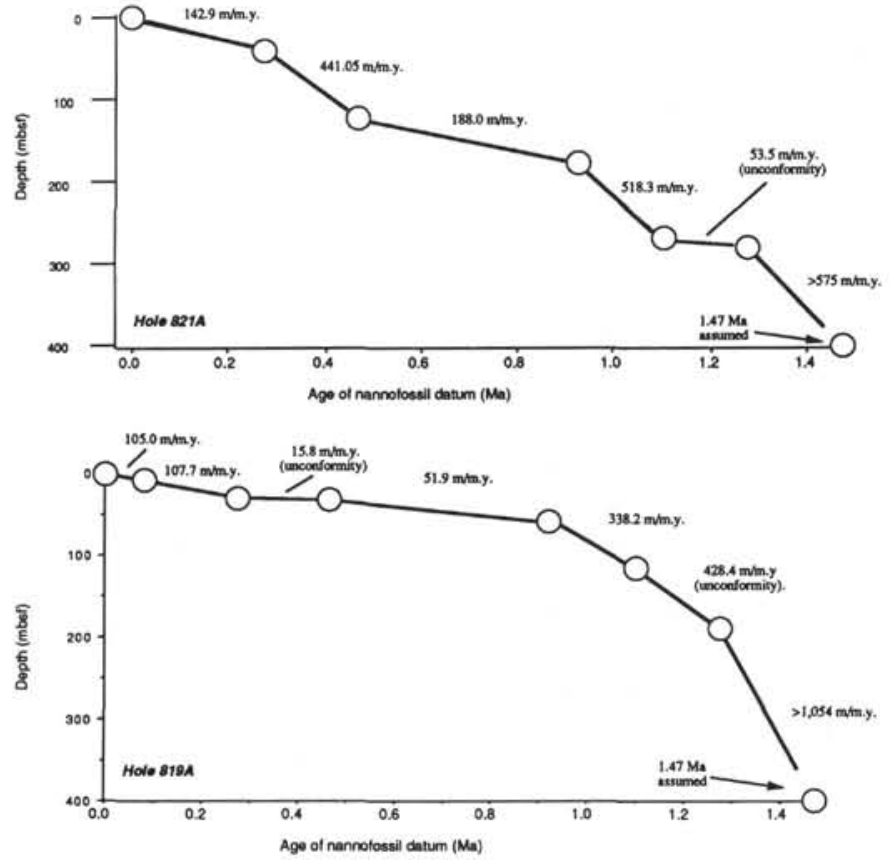

Figure 1. Plot of depth vs. age and sedimentation rates for Holes 819A and $821 \mathrm{~A}$ from the data of Table 1 . The highest accumulation rates occur in the basal sections at both sites.

glacial climate at about $0.5 \mathrm{Ma}$ (Williams et al., 1988; Ruddiman et al., 1989; Joyce et al., 1990).

Figures 2 and 3 show the relationship between the bundling of calcium carbonate and magnetic susceptibility variations and other important sedimentologic and geochemical parameters recorded at Sites 819 and 821 . In most cases, these low carbonate/high susceptibility bundles may be interpreted as pulses of fine-grained siliciclastic influx, predominantly in the form of silts and clays, that dilute the percentage of calcium carbonate and at the same time contain finegrained, magnetically susceptible detrital minerals. A typical sandline/clayline plot of wireline gamma-ray intensity (such as routinely employed in siliciclastic settings) is shown in Figure 2. There, the bundling of increasing magnetic susceptibility and decreasing calcium carbonate covaries with increases in the percentage of fine fraction (percentage "mud") and increases in downhole gamma-ray activity. This covariation is especially true for the lower portion of the hole. In the upper portion of the hole, the bundles also appear to vary in a general way with increasing proportions of siliciclastic sands. At the more proximal Site 821 , decreasing calcium carbonate/increasing magnetic susceptibility bundles clearly correlate with pulses of sedimentation marked by increases in glauconite (and minor siderite and iron oxyhydroxides), sand-sized detrital siliciclastics, and sand-sized (nonforaminiferal) bioclasts (Fig. 3). There, iron-bearing glauconite appears to be providing another important source of magnetization to the sediments. Thus, surprisingly, the source of the variations in magnetic susceptibility at these closely related sites appears to stem from two principal sources that tend to dominate each: detrital clays and iron compounds at Site 819, and detrital clays and (iron-bearing) glauconite at Site 821 . In addition, the relationship of these bundles to sequence-stratigraphic architectures is especially clear at Site 821 (Fig. 3; also see Glenn et al., this volume); the carbonate/magnetic susceptibility bundles correlate with two discrete phases during the development of each transgressive systems tract/highstand systems tract couplet, one in association with downlapped maximum flooding surfaces when clays reach a maxima, and the other with late highstand 


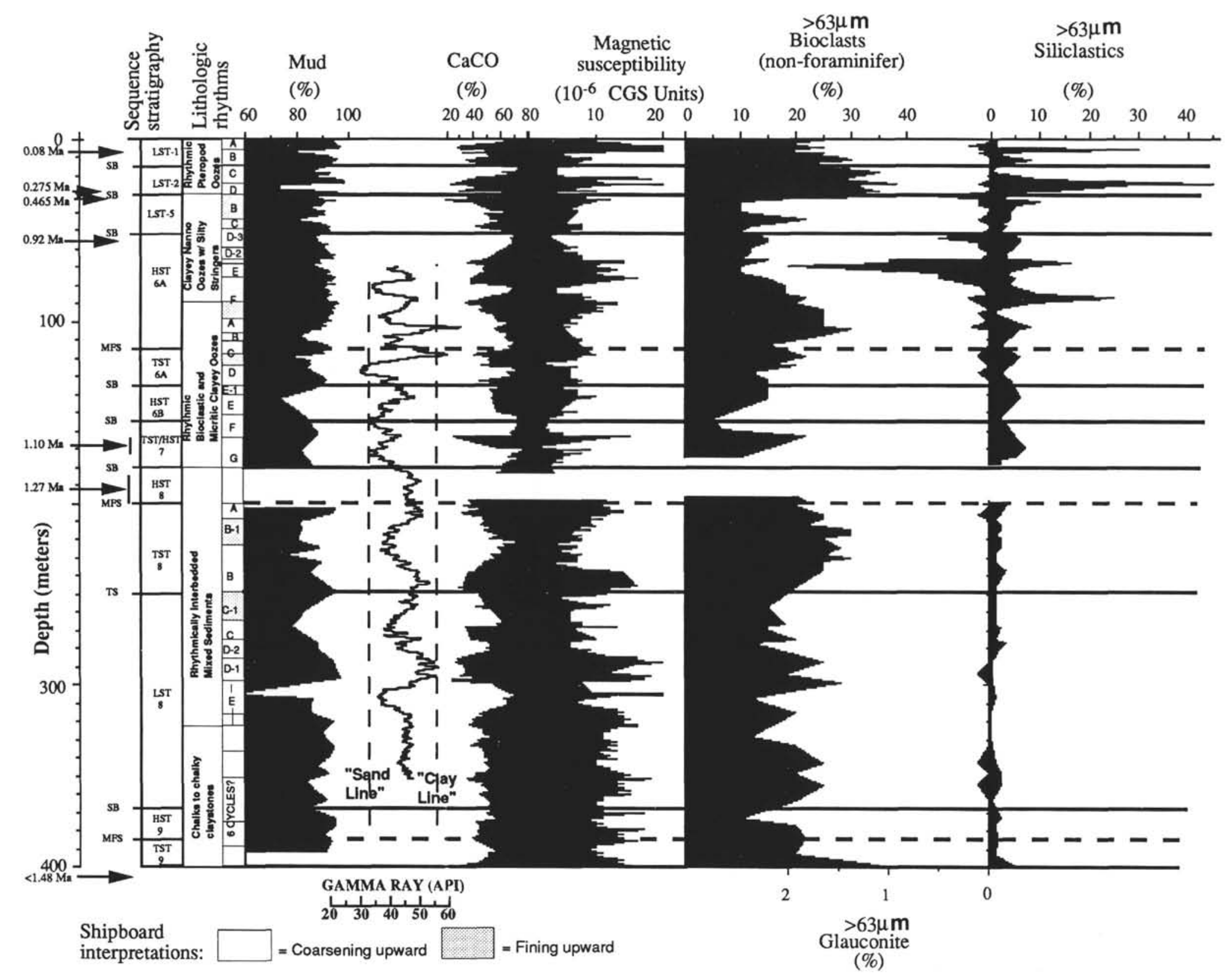

Figure 2. Sedimentary, geochemical, gamma-ray, and sequence-stratigraphic data for Hole 819A. Coarsening- and fining-upward cycles are indicated from sequence-stratigraphic interpretations from Glenn et al. (this volume). SB = sequence boundary, MFS = maximum flooding surface, TS = transgressive surface, LST = lowstand systems tract, TST $=$ transgressive systems tract, HST $=$ highstand systems tract. Nannofossil datums of Table 2 also are shown. 


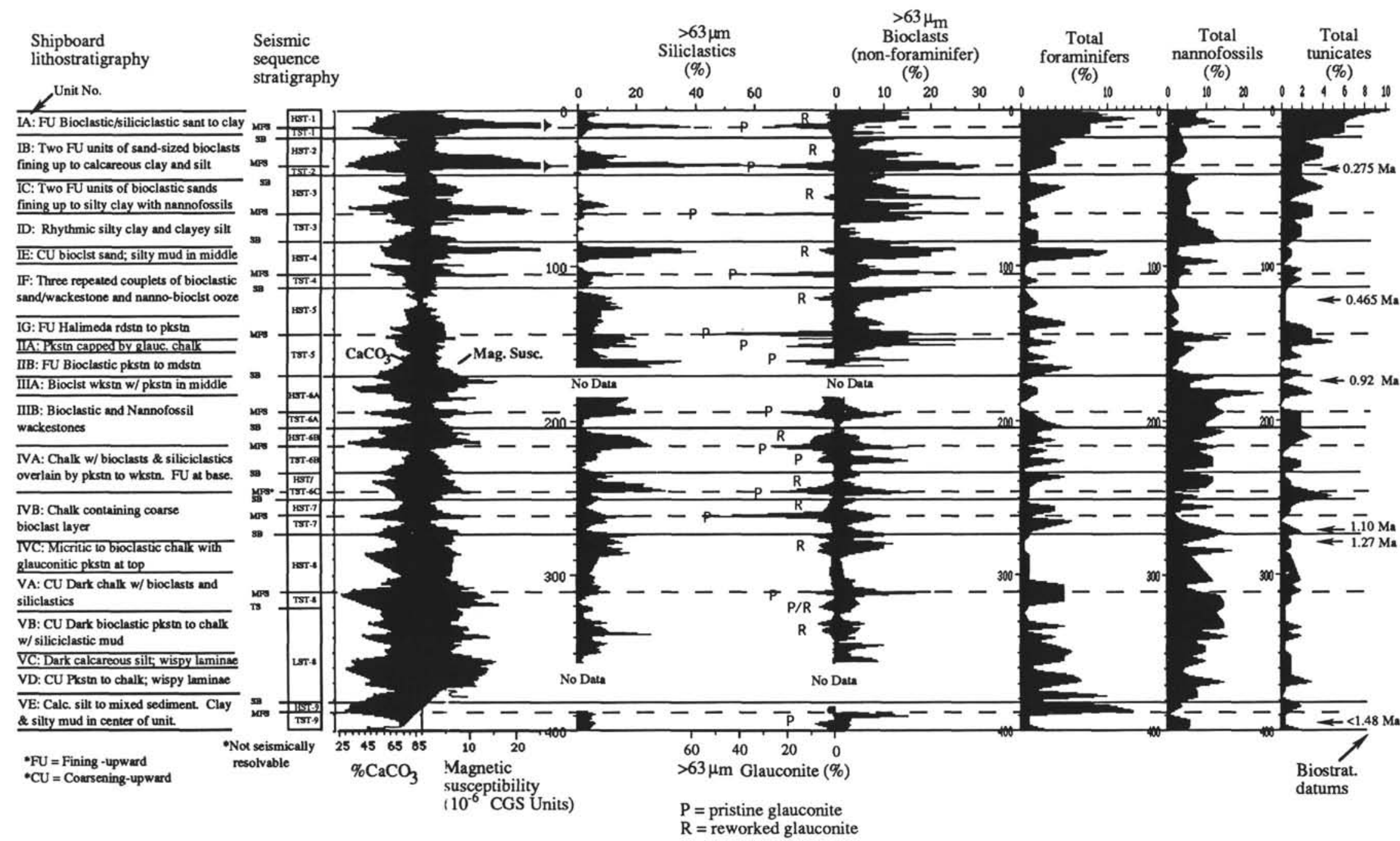

Figure 3. Sedimentary, geochemical, gamma-ray, and sequence-stratigraphic data for Hole 821A. The shipboard lithostratigraphy includes lithostratigraphic unit numbers and the positions of fining-and coarsening-upward cycles. The sequence boundary at about $170 \mathrm{mbsf}(\sim 0.92 \mathrm{Ma})$ separates a largely progradational seismic package that is characterized by an abundance of coarsening-upward cycles below from a largely aggradational seismic package characterized by multiple fining-upward cycles above. Sequence-stratigraphic interpretations are from Glenn et al. (this volume). Nannofossil datums of Table 2 also are shown. See Figure 2 for key to abbreviations. 


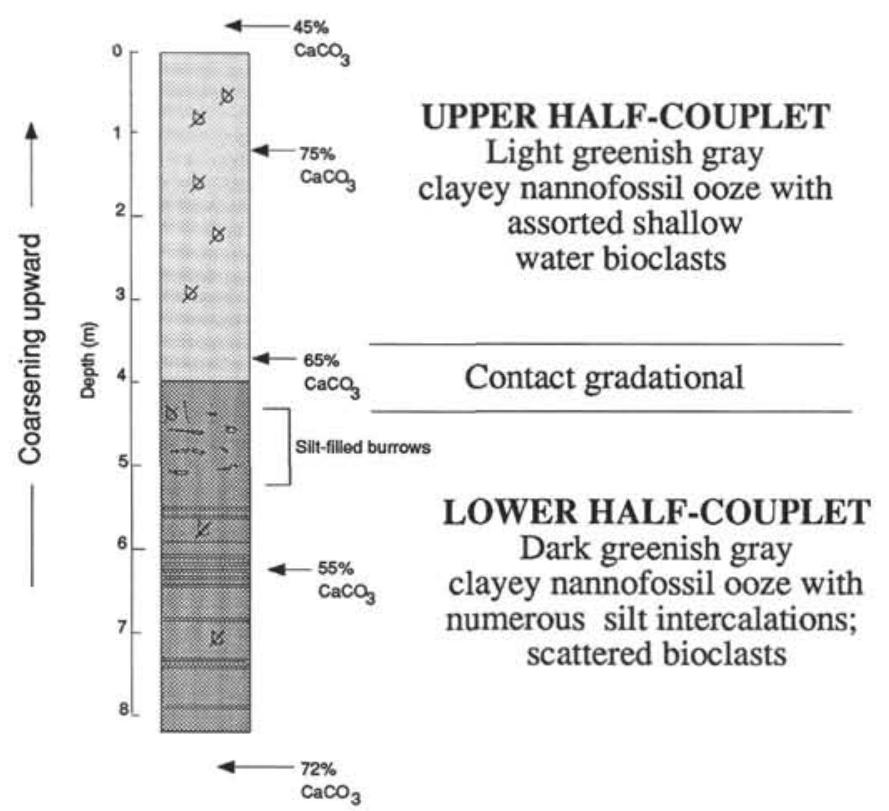

Figure 4. Detail of the two half couplets composing one upward-coarsening cycle (cycle E-1 at about 140 mbsf) at Hole 819A (See Fig. 2).

systems tract progradation. At Site 821, therefore, these bundles and their variations clearly track relative changes in sea level for the past $\sim 1.48 \mathrm{Ma}$.

\section{Fourier Analyses}

To investigate further the periodicity of the sedimentary cycles recovered in the Great Barrier Reef Transect, we computed a Fourier analysis of magnetic susceptibility and downhole sonic velocity data collected at Hole 821 A. Plots of the raw data sets vs. interpolated age are shown in Figures 7 and 9, and Fourier analysis results are shown in Figures 8 and 9. The time scale used for the Fourier analyses was interpolated from the nannofossil datums presented in Table 2 and Figure 1. The time scale has not been "tuned" in any way (e.g., Shackleton et al., 1990). Intervals initially chosen for these analyses were based on overlapping windows of equal duration. However, in instances where the overlapping windows crossed large steplike variations in the data, the analysis program employed showed difficulty in removing low-amplitude background trends. In these cases, no significant cyclicity could be recovered from the data set. Thus, for example, following the top three overlapping windows of equal duration shown in Figure 7 (i.e., 0-200 ka, 150-350 ka, and 300-500 $\mathrm{ka}$ ), the size of the window analyzed had to be adjusted to match those portions of the record displaying a relatively uniform background trend to which a third-order polynomial expression could be fit and subsequently removed. The windows selected for the fast Fourier analyses of downhole sonic velocity variations were similarly selected (Fig. 9). In the following we discuss any semblance the results portrayed in Figures 8 and 9 have to the Milankovitch periods, as well as to other causal mechanisms.

\section{Fourier Transforms of Magnetic Susceptibility Data}

The top three windows shown in Figure 8 are the results of fast Fourier transforms for magnetic susceptibility data computed for three equally spaced, overlapping time slices of equal duration. The first two of these analyses indicate cyclicity in the data, which closely matches the dominant periods of Milankovitch orbital variables at 100 k.y./cycle (period of eccentricity), about 41 k.y./cycle (obliquity), and at 25 and $20 \mathrm{k} . \mathrm{y} . / \mathrm{cycle}$ (precession). The dominant spectral peaks in

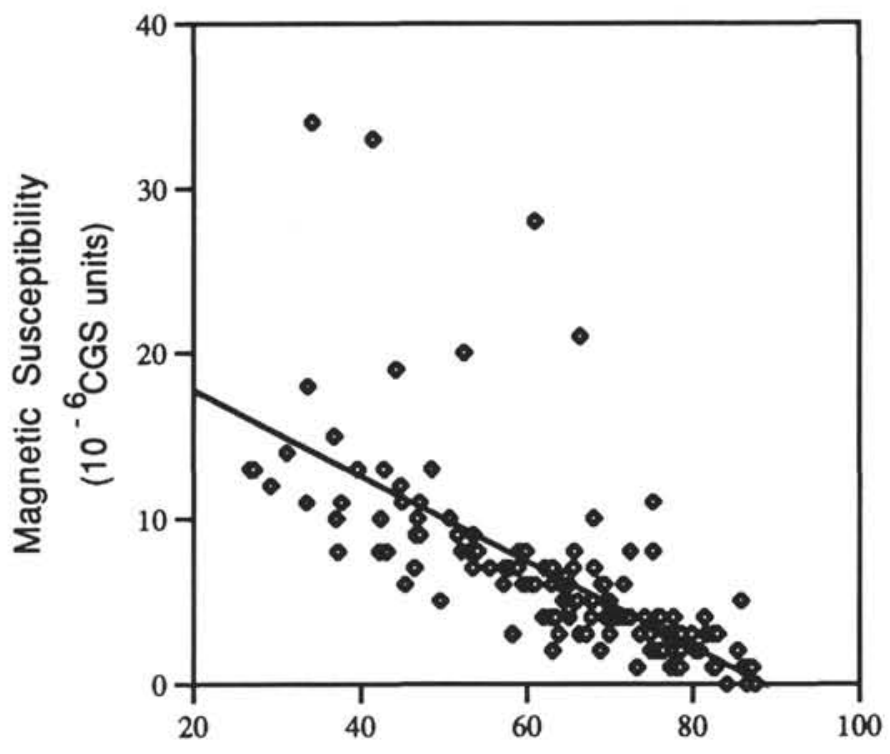

Percent $\mathrm{CaCO} 3$

Figure 5. Cross plot of magnetic susceptibility and calcium carbonate for Hole $821 \mathrm{~A}$ illustrating the negative covariance between these parameters and the lack of reduction diagenetic overprinting.

these data are those of the eccentricity cycle and suggest slightly less than four 100-k.y. carbonate/magnetic susceptibility bundles spanning seismic Sequences 1 through 3 . The results from the other, older time windows analyzed, however, only show suggestions for the eccentricity cycle. The obliquity cycle is also present in these windows. The longest and most condensed interval analyzed covers most of the data from seismic Sequence 5. Fourier analysis of this sequence illuminates both the 400- and 100-k.y. eccentricity cycles, and the broad peak at $45 \mathrm{k} . \mathrm{y}$. also suggests the presence of the obliquity beat. The cycles of precession appear to be loosely represented by spectral peaks that range between about 16 and 25 cycles/k.y. throughout most of the intervals analyzed. The 41-k.y. obliquity cycle also appears fairly well represented throughout and appears to increase in magnitude downcore. Differences between observed and predicted peaks may be caused by errors in sedimentation rate calculations, a likely possibility in light of the spread of nannofossil datums that separates the numerous seismic sequence tracts.

The Fourier results for magnetic susceptibility also reveal a common spectral peak at about $30 \mathrm{k} . \mathrm{y} . / \mathrm{cycle}$ in the intervals spanning seismic Sequences 3, 4, and 6, as well as a peak at about 50 k.y./cycle in the intervals spanning seismic Sequences 3 and 6 . These peaks may be artifacts because of aliasing of the data from higher frequency "noise" in the data set (cf. Pisias and Mix, 1988), from variations in sedimentation rates occurring below the resolution of our age control (cf. Pisias and Mix, 1988), or from resonance, interference, or smearing from neighboring frequency bands (e.g., Martinson et al., 1982, 1987). However, it is also possible that some of these periods are being produced by depositional cyclicity operating at a cadence other than at the unit-value Milankovitch periods. Close inspection of Figure 3 shows multiple, covarying pulses in magnetic susceptibility, percentage of carbonate, and percentage of glauconite within individual seismic sequences. On average, these pulses subdivide the duration of seismic Sequences 3, 4, and 6A into periods of duration that roughly correspond to the $\sim 30$ - and 50-k.y. periods seen in the FFT results (Table 3). Also note that, within the relatively condensed interval of seismic Sequence 5, there is one major carbonate/magnetic susceptibility bundle having a duration of $443 \mathrm{k} . \mathrm{y}$. that contains four major pulses in glauconite. These subdivide the bundle, on average, into four 


\section{Hole 819A}

\section{Holes 821A and 821B}

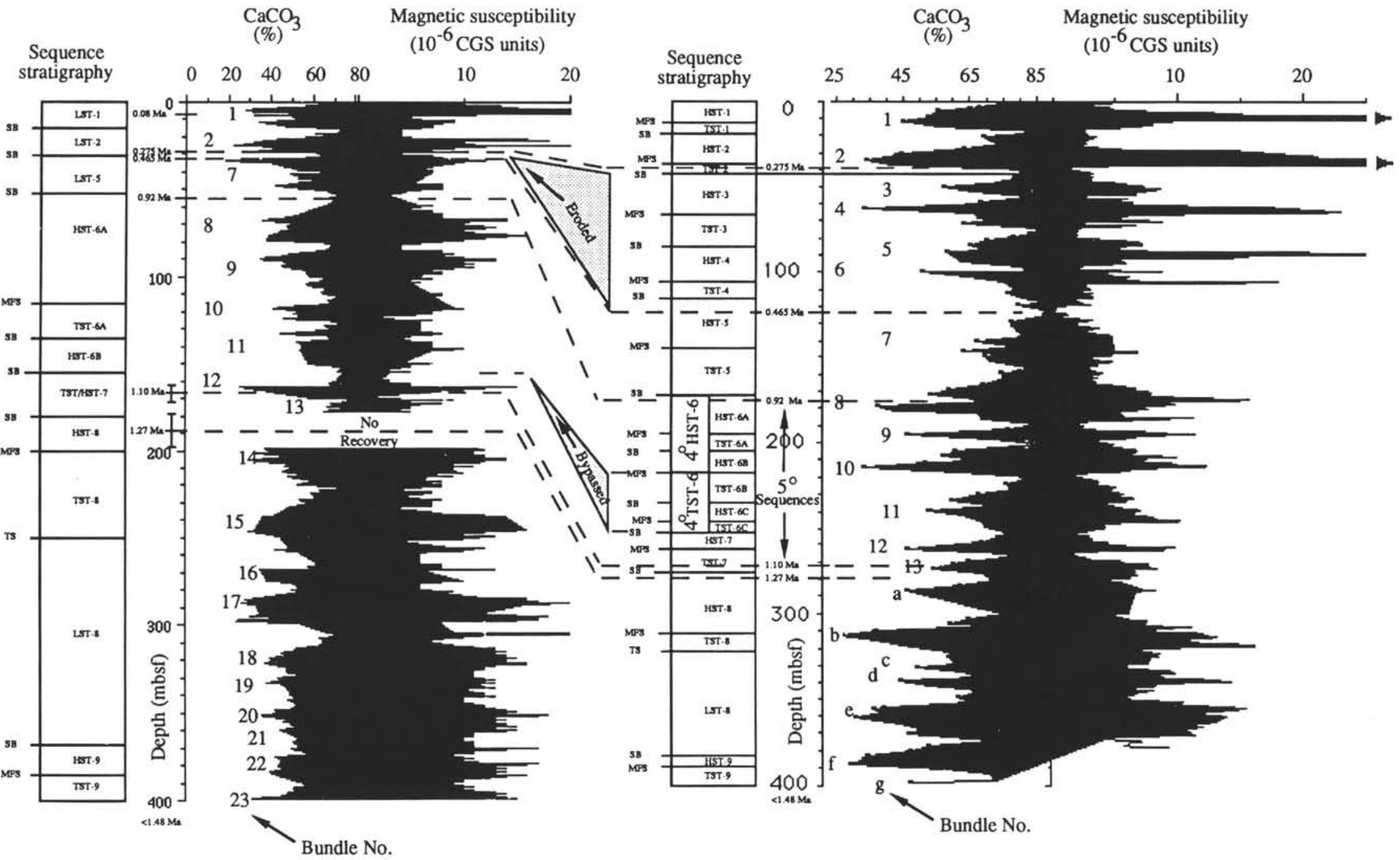

Figure 6. Bundles of decreasing calcium carbonate and increasing magnetic susceptibility at Holes 819A, 821 A, and 821B. Also shown are the correlation of nannofossil datums from Table 2 and the correlation of sequence-stratigraphic interpretations (data from Glenn et al., this volume). Most of the sequences indicated are fourth-order ( 100-500 k.y.) in duration, but fifth-order sequences subdividing Sequence 6 also are observed. Note that Sequences 3 and 4 and the fourth-order TST-6 are missing at Site 819 and that a major unconformity can be seen between about 1.10 and 1.27 Ma at both sites. 


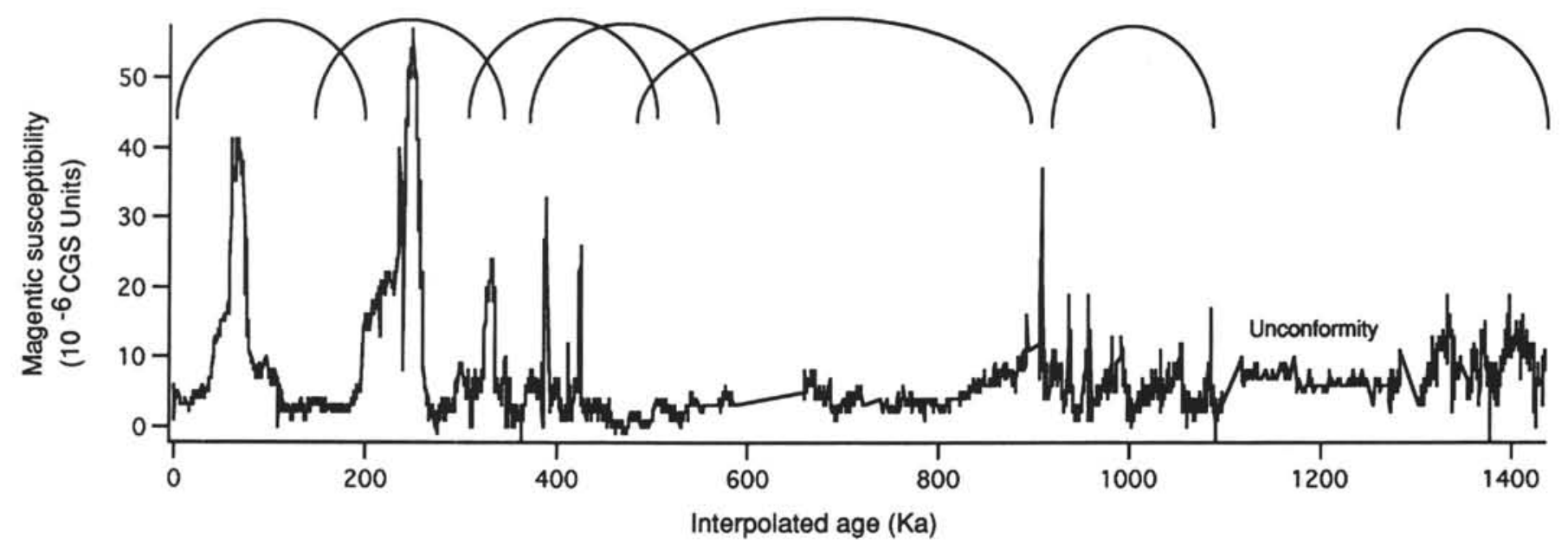

Figure 7. Plot of magnetic susceptibility vs. age for Hole 821A. Age data are those interpolated between nannofossil datums. The hemispherical curves adjacent to the plot show the positions of age windows for fast Fourier transforms.

periods of $110 \mathrm{k.y}$. (Table 3). These durations and periods closely match the 400- and 111-k.y./cycle spectral peaks calculated for these intervals from Fourier transforms (Fig. 8). Similarly subdivided on an average basis (Table 3), seismic Sequence 6, spanning a total duration of 173 k.y., shows a variety of durations at 17, 21, and 25 k.y., which appears to match the mean periods of orbital precession. In light of these potential matches, we suggest that these latter periods may be produced by the stacking of parasequence sets within systems tracts (see Van Wagoner et al., 1990), although further study is clearly needed to test this hypothesis.

\section{Fourier Transforms of Sonic Velocity Data}

Fast Fourier transform results for available downhole sonic velocity data collected at Hole 821 A are presented in Figure 9. In this case, the raw data are limited to the portion of the hole below the drill string. As for the FFT spectra of the magnetic susceptibility data, the results show a fair correspondence to the master periods of orbital eccentricity, obliquity, and precession, but with differing spectral densities for different portions of the core.

The 336- to 446-ka window shows strong spectral density near the periods of obliquity and precession. The result also shows a large amount of low-frequency noise. This noise may be the result of complications due to a mixture of elevated sedimentation rates, interbedded rhythmic silty clays and clayey silts, and coarsening- and finingupward units, all within this interval ( $66-115$ mbsf; Fig. 3). The narrowness of the window also appears to preclude the detection of eccentricity cycles. The two subsequent windows (459-660 ka and $660-890 \mathrm{ka})$ are from the stratigraphically condensed ( $130 \mathrm{~m} / \mathrm{m} . \mathrm{y}$.) seismic Sequence 5 highstand and transgressive systems tracts, respectively. These units encompass a number of 4- to 14-m-thick, fining-upward depositional cycles and show progressively decreasing spectral densities for eccentricity, obliquity, and precession within each time window. As for several of the magnetic susceptibility results discussed above, the sonic velocity signal also appears to contain the signature of a $\sim 30 \mathrm{k} . \mathrm{y} . / \mathrm{cycle}$ within this portion of the record. The 925- to 985-ka window is for highstand systems tract 6 and shows a strong precessional peak; this window is too small to resolve obliquity or eccentricity forcing. The oldest window (1295-1451 ka) encompasses seismic Sequence 8, which contains upward-coarsening depositional units. The Fourier transform for this window shows spectral peaks at 80,40 , and about 23 k.y./cycle; the $80-$ k.y. peak is likely an artifact resonance tone.

\section{Comparisons with Orbital-Parameter Time Series}

Figure 10 illustrates the time series variations in magnetic susceptibility, carbonate content, and sequence stratigraphy, as compared to calculated orbital parameters (Berger, 1978). From this figure (and the results above) several points appear that link the development of sequence-stratigraphic units with sea-level variations associated with orbital climate forcing. The last 350 k.y. of the record at Site 821 shows a well-developed cyclicity of fining-upward marine sedimentary cycles that bundle into six seismically resolvable systems tracts (seismic Sequences 1 through 3 ) that, in turn, bundle into the most recent longterm cycle of eccentricity (Fig. 10). The average duration of these seismic sequences is 127 k.y. Cycles of eccentricity, obliquity, and precession are all recorded within this interval in magnetic susceptibility data (Fig. 8). Fourier analysis data encompassing seismic Sequence 4 (300-500 ka and 375-575 ka magnetic susceptibility FFTs; 336-446 ka sonic velocity FFTs), however, show a lack or strong diminishment of the eccentricity spectra within this interval (Figs. 8 and 9). This diminishment correlates with eccentricity minima at about $400 \mathrm{ka}$ calculated from orbital mechanics (Fig. 10). Seismic Sequence 5 represents one long-term, $400-k . y$. cycle of eccentricity (Fig. 9). The sequence spans four 100-k.y. cycles of eccentricity (Figs. 8, 9, and 10) and is marked by a major maximum flooding surface at its midpoint $(0.66 \mathrm{Ma})$. The four eccentricity cycles appear to correlate with three progressive flooding events in the Sequence 5 transgressive systems tract and one progradational event in the Sequence 5 highstand systems tract (Figs. 3 and 10). Seismic Sequence 6 centers on a maximum flooding surface at about $1 \mathrm{Ma}$ and lacks evidence for obliquity forcing in both the magnetic susceptibility and sonic velocity Fourier results. This flooding surface temporally correlates with a major change in the mode of Pleistocene climate, as indicated from global oxygen isotope records; these records globally switch at this point from the high-frequency/low-amplitude signals of the Pliocene-early Pleistocene to the low-frequency/high-amplitude signals of the late Pleistocene (e.g., Shackleton and Opdyke, 1976; Prell, 1982; Williams et al., 1988; Ruddiman et al., 1989). In addition, the work of Joyce et al. (1990, Gulf of Mexico) suggests that orbital climate modulation switched following this point from obliquity-dominated to eccentricity-dominated and that 1 Ma marks distinct nodes of eccentricity and obliquity and precession minima. This change at about $1 \mathrm{Ma}$ also closely corresponds to a major change from prograding to aggrading seismic architectures in this region (Symonds et al., 1983, and other papers in this volume). Unfortunately, however, the narrowness of our FFT 

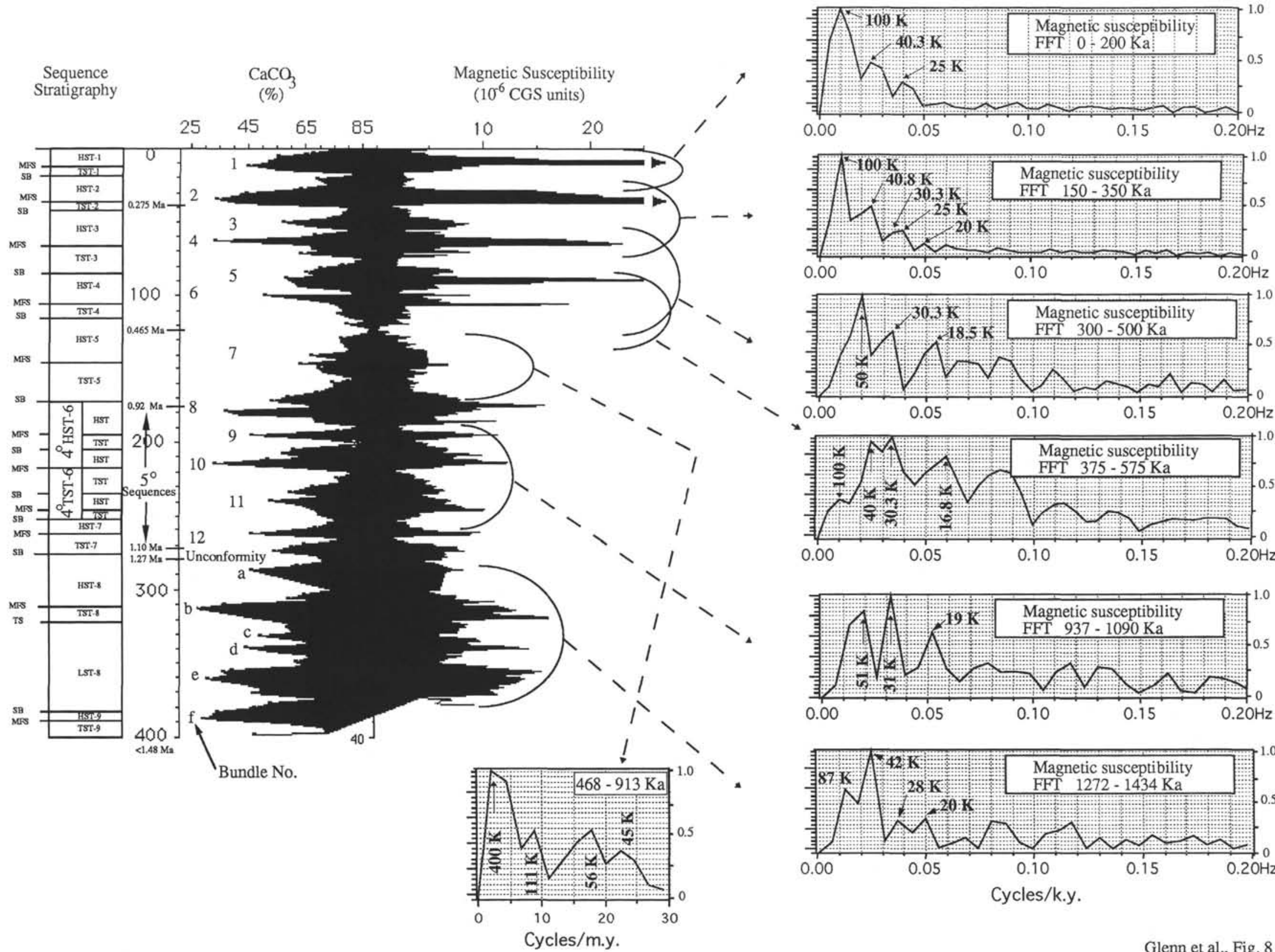
Figure 8. Power spectra from Fourier results for magnetic susceptibility data from Hole 821A. Vertical axis of spectral amplitude is normalized to the peak displaying the highest power to provide percentage of total variance. Periods for peaks are shown in k.y./cycle. See Figure 2 for key to abbreviations. 

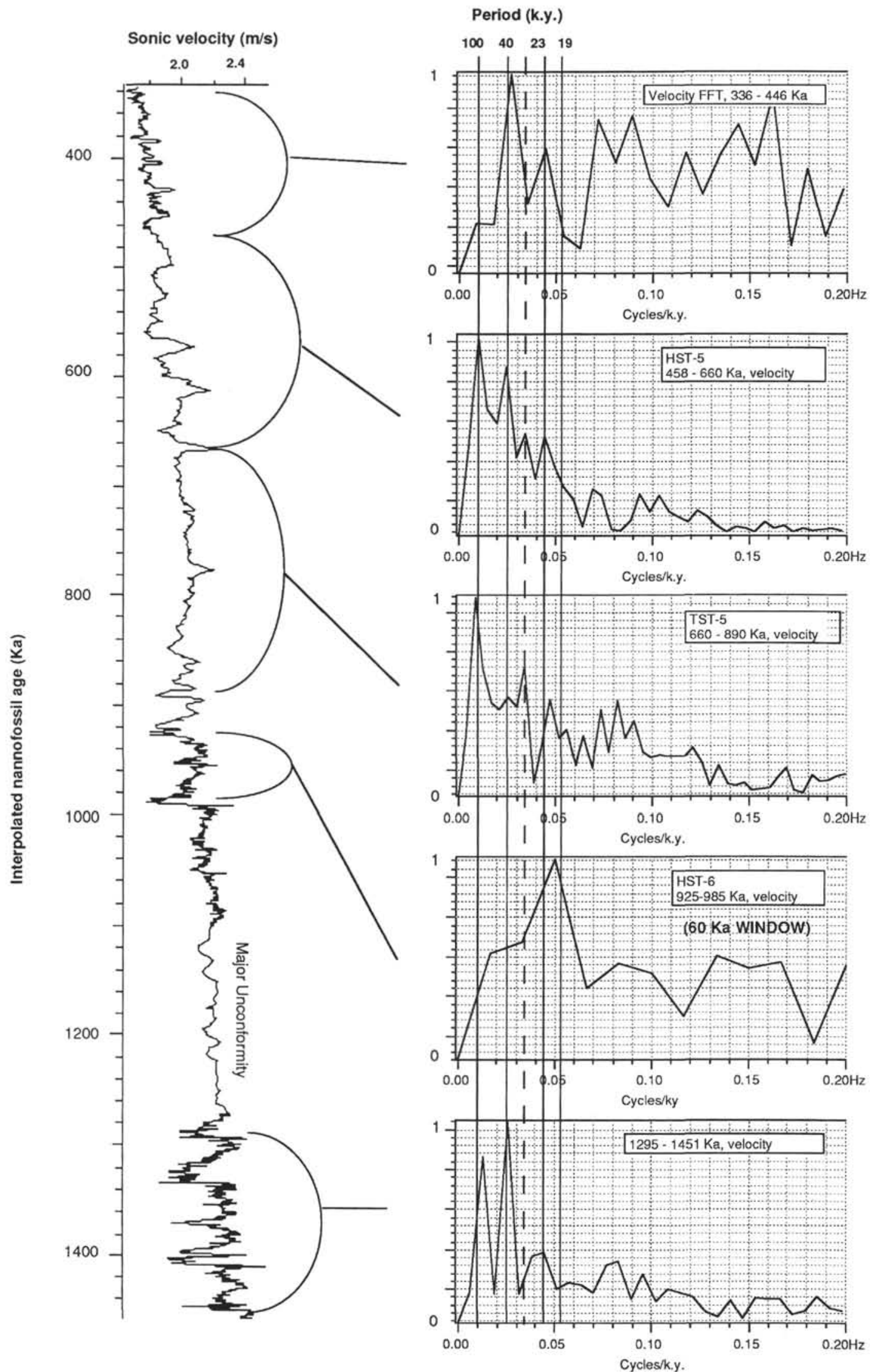

Glenn et al., Fig. 9

Figure 9. Fourier results for continuous downhole sonic velocity from Hole 821A (66-392 mbsf). Sonic velocity data were not collected above this interval. Vertical axis of spectral amplitude is normalized to the peak displaying the highest power to provide percentage of total variance. Dashed line corresponds to a period of $30.3 \mathrm{k} . \mathrm{y}$. 
Table 3. Temporal subdivision of seismic sequences on the basis of carbonate/magnetic susceptibility bundling and/or pulsations in glauconite sedimentation at Holes $821 \mathrm{~A}$ and $821 \mathrm{~B}$.

\begin{tabular}{|c|c|c|c|c|}
\hline $\begin{array}{l}\text { Seismic } \\
\text { sequence }\end{array}$ & $\begin{array}{c}\text { Average } \\
\text { duration } \\
\text { (k.y.) }\end{array}$ & $\begin{array}{c}\text { Magnet } \\
\text { bundles } \\
\text { (No.) }\end{array}$ & $\begin{array}{c}\text { Glauconite } \\
\text { pulses } \\
\text { (No.) }\end{array}$ & $\begin{array}{l}\text { Average duration } \\
\text { per pulse (k.y.) }\end{array}$ \\
\hline 1 & 133 & 1 & 2 & $\begin{array}{c}133 \\
66.5\end{array}$ \\
\hline 2 & 146 & 2 & 2 & $\begin{array}{l}73.0 \\
73.0\end{array}$ \\
\hline 3 & 102 & 3 & 2 & $\begin{array}{l}34 \\
51\end{array}$ \\
\hline 4 & 64 & 2 & 2 & $\begin{array}{l}32 \\
32\end{array}$ \\
\hline 5 & 443 & 1 & 4 & $\begin{array}{l}443 \\
110\end{array}$ \\
\hline $6 \mathrm{~A}$ & 88 & 3 & & 29.3 \\
\hline $6 \mathrm{~B}$ & 51 & 2 or 3 & 3 & $\begin{array}{c}25,17 \\
17\end{array}$ \\
\hline $6 \mathrm{C}$ & 34 & 2 & 2 & $\begin{array}{l}17 \\
17\end{array}$ \\
\hline 6 ( $4^{\circ}$-order $)$ & 173 & 7 or 8 & & 21,25 \\
\hline 7 & 128 & 2 & 2 & $\begin{array}{l}64 \\
64\end{array}$ \\
\hline 8 & 249 & 4 & & 62 \\
\hline
\end{tabular}

windows (e.g., 937-1090 ka for magnetic susceptibility and 925-985 ka for velocity) prohibits accurate discrimination for eccentricity in this portion of the GBR record.

\section{DISCUSSION}

How are the Milankovitch periods transferred from the top of the atmosphere to the magnetic and sonic velocity data recorded in Hole $821 \mathrm{~A}$ ? Both of these parameters are linked in that they may reflect proportions of fine-grained siliciclastics contained in these sediments, the first as a direct measurement of fine-grained magnetic minerals, insoluble residues, and glauconite, and the second as an indirect measure of porosity (e.g., Bloemendal and deMenocal, 1989; Jarrard and Arthur, 1989). These physical properties of the sediments varied in cadence with changes in sea level deduced from sequence analysis and also recorded the beat of glacial/interglacial change suggested in Fourier spectra. However, what remains unknown is how the variations in siliciclastic influx were regulated by Milankovitch forcing and how this forcing explicitly impacts and modulates the sequence-stratigraphic record. Such modulation undoubtedly involved many variables, including lags in the climate and oceanic response to orbitally produced solar radiation changes (e.g., Aharon, 1984; Short and Mengel, 1986), and independent variations in sediment supply and tectonic subsidence. Together, these variables regulate available accommodation space and, therefore, control the type of sequence and systems tracts that develop at different locales even during global eustatic events (Fulthrope, 1991; Reynolds et al., 1991). Also complicating the record at Site 821 is the general lack of lowstand systems tracts and, thus, the likely expanded hiatuses associated with most sequence boundaries. Furthermore, we are still unsure how the waxing and waning of siliciclastic detritus in these sediments relate to aridity/rainfall cycles, if at all. Peaks in magnetic susceptibility (clay and glauconite), bioclasts, and quartz clearly relate to maximum flooding and highstand progradational events at Site 821 , yet we do not know if these peaks are reflecting increases in siliciclastic transport due to increases in rainfall and runoff or if they represent an eolian component that becomes more predominant during times of sequence condensation. In siliciclastic-dominated depositional sequences, peaks in clay abundances along downlapped surfaces are commonly interpreted as representing sequence condensation as a result of nearshore trapping of detrital clastics during maximum flooding. At Site 821, however, the increases in clays along downlapped surfaces are also associated with relative increases in quartz and seem to necessitate relative increases in terrigenous influx, either by wind or water, during these times.

The Great Barrier Reef Province lies almost entirely within the tropics and forms a meridional mass between the Australian continent and the vast oceanic region of the South Pacific Ocean. Strongly influenced by both of these regions, the province is subjected to all the influences of intertropical oceanic weather patterns (Maxwell, 1968). Summer southeast tradewinds release heavy rains as they move into the unstable air masses of the equatorial zone and the continent. In addition, high summer rainfall is maintained by contributions from northwest summer monsoons, which result from winter cooling in Asia and southeast Coriolis deflection on crossing the equator. The monsoons bring moist air from the warm equatorial seas to the northern continent and its marginal seas. Global climate modeling and Fourier spectral results indicate that the intensity of these monsoons, at least in Asia where they were born, was regulated by glacial/interglacial cycles and is coherent and in phase with a 23-k.y. precessional beat (Prell and Van Campo, 1986; Prell and Kutzbach, 1987). However, it is not clear from these results whether monsoons may have penetrated to the northeastern Australian margin. In addition, tropical cyclones strongly affected the margin by bringing heavy rainfall in summer months and early autumn (Maxwell, 1968). Even today, infrequent cyclones and extremely heavy cyclonic rainfall transport large volumes of terrigenous clastics across the shelf and out through the outer reefs (Davies et al., 1985). In that such seasonal weather patterns have been shown to have a strong tie to orbital climate forcing, it remains a tantalizing objective to determine the possibility of their linkage to the Milankovitch cyclicity observed in the GBR margin sediments.

\section{SUMMARY AND CONCLUSIONS}

The results discussed above strongly suggest that the sedimentary cyclicity observed at Site 821 has in some way been controlled or at least modulated by climatic and oceanic forcing in the Milankovitch waveband. All the dominant periodicities of eccentricity, obliquity, and precession are present within the record at this site, although with differing intensities for different depositional packages and time frames. From the results presented above, the following conclusions can be drawn:

1. Variations in carbonate content and magnetic susceptibility in the GBR slope sediments bundle into rhythmic alternations between high-magnetic-susceptibility/low-carbonate bundles and low-magnetic-susceptibility/high-carbonate bundles. These bundle pairs tend to form couplets that correspond to the transgressive and highstand systems tracts identified from sequence-stratigraphic analysis.

2. Magnetic susceptibility/carbonate cycles have been interpreted as pulses of fine-grained siliciclastics that dilute percentages of carbonate and at the same time contain fine-grained, magnetically susceptible detrital minerals. At Site 821 , these pulses occurred during times of maximum flooding (along downlapped surfaces) and subsequent highstand progradation. During maximum flooding events, these pulses were marked by dramatic increases in quartz, bioclasts, and unreworked authigenic mineral phases (glauconite and siderite). During highstand progradational events, the pulses were marked by increases in silt, bioclasts, and reworked glauconite. The magnetic susceptibility/carbonate bundles observed at Site 821 thus mimic relative changes in sea level. 


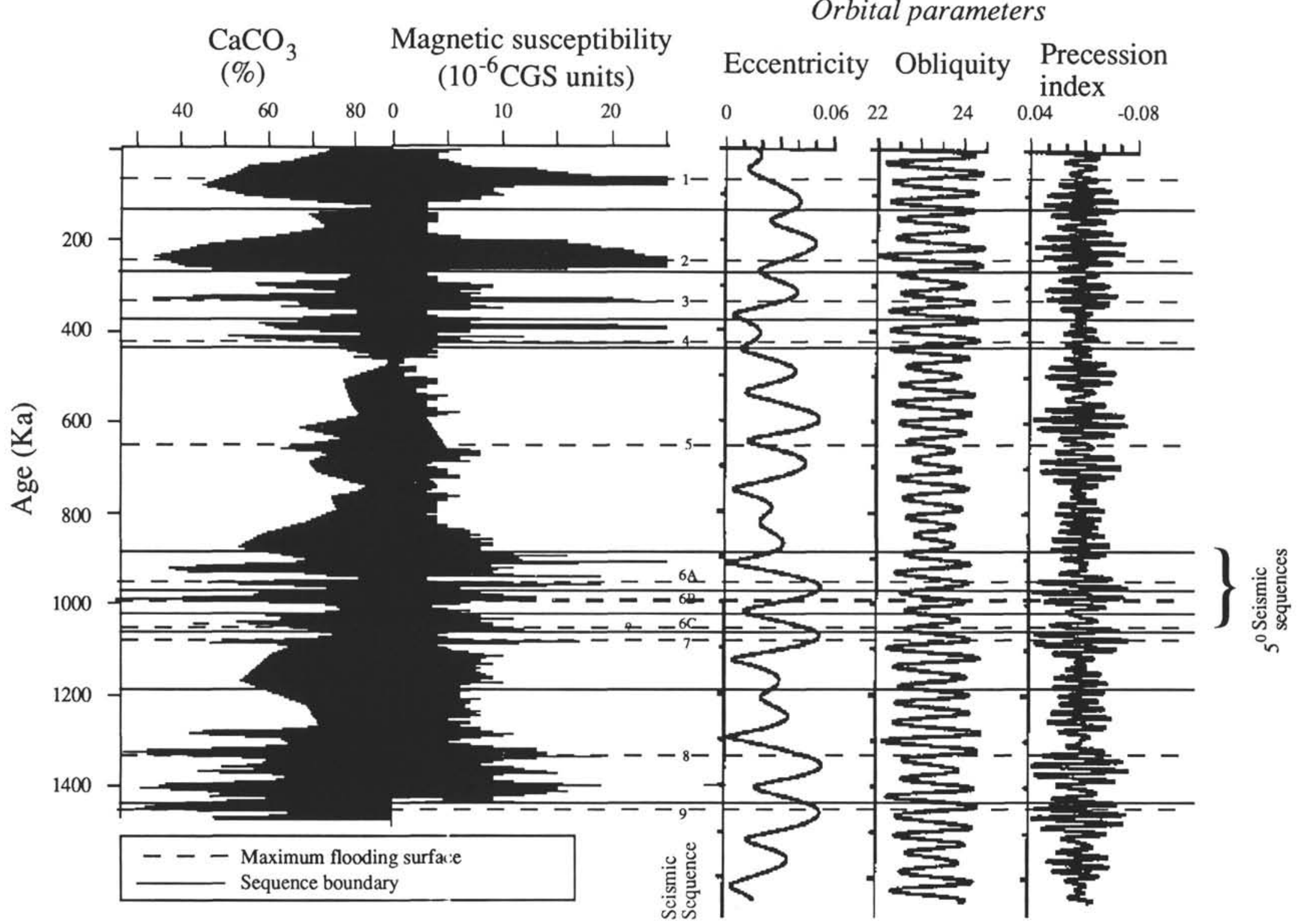

Figure 10. Time series of carbonate and magnetic susceptibility data for Hole 821 compared with orbital eccentricity, obliquity, and precession (using the precessional index, $e$ sin $w$ ) over the last 1.65 Ma (from Berger, 1978). Seismic sequences of Glenn et al. (this volume) also are shown. 
3. The most recent 350 k.y. of the record at Site 821 shows a well-developed cyclicity of fining-upward marine sedimentary cycles that bundle into six seismically resolvable systems tracts (seismic Sequences 1 through 3 ) that, in turn, bundle into the most recent long-term cycle of eccentricity (Fig. 10). The average duration of these seismic sequences was $127 \mathrm{ka}$. Recorded within this interval in magnetic susceptibility data (Fig. 8) are 100-, 41-, and 20- to 25-k.y. cycles of eccentricity, obliquity, and precession. Eccentricity dominates cyclicity in this interval.

4. Seismic Sequence 4 is marked by relatively high sedimentation rates (averaging 436 Bubnoffs) that occurred over a relatively short time span (64 k.y.). Fourier analysis data encompassing this interval (300-500 ka and 375-575 ka magnetic susceptibility FFTs; 336-446 ka sonic velocity FFTs) show a diminishment of the 100-ka spectral peak within this interval (Figs. 8 and 9), which may correlate with the eccentricity minima at about 400 ka calculated from orbital mechanics (Berger, 1978; Fig. 10). This minima in eccentricity was directly preceded by a long-term change at Site 821 from upward-increasing carbonate/decreasing magnetic susceptibility (decreasing bundle widths) to upward-decreasing carbonate/increasing magnetic susceptibility (increasing bundle widths) at about $0.465 \mathrm{Ma}$. This change also may have marked the late Pleistocene switch to a strong eccentricity-dominated climatic mode, described from North Atlantic Ocean records.

5. Seismic Sequence 5, the most stratigraphically condensed interval, is marked by relatively low sedimentation rates (averaging 133 Bubnoffs) that occurred over a relatively long time span (443 k.y.) and represents one long-term cycle of eccentricity (Fig. 10). The sequence, spanning four 100-k.y. cycles of eccentricity (Figs. 8, 9, and 10 ), is marked by a major maximum flooding surface at its midpoint $(0.66 \mathrm{Ma})$. The four eccentricity cycles appear to correlate with three progressive flooding events in the Sequence 5 transgressive systems tract and one progradational event in the Sequence 5 highstand systems tract.

6. Seismic Sequence 6 is marked by high sedimentation rates ( 446 Bubnoffs). These high rates provide for increased resolution within this unit and its subdivision into three fifth-order, sequence-stratigraphic cycles of sea-level change (Sequences 6A, 6B, and 6C). Covering approximately one and a half 100-k.y. eccentricity cycles (Fig. 10), the Fourier spectra for this interval show no evidence for obliquity climate forcing; spectral power in the precessional bandwidth is, however, present. The width of the windows analyzed precludes detection of eccentricity signals within this interval. This unit centers at about $1 \mathrm{Ma}$ and marks the change from long-term, thirdorder progradational to aggradational stratigraphic architectures and a dramatic increase in shallow-water bioclast production and decrease in nannofossil abundances. It also temporally correlates with a dramatic shift in the mode of Pleistocene climates, as deduced from deep-sea oxygen isotope records, and appears to have been deposited during an initial change from obliquity-dominated to eccentricitydominated climate modulation.

7. On average, pulses in magnetic susceptibility, percentage carbonate, and percentage glauconite subdivide the duration of many of the seismic sequences into periodicities that roughly correspond to either the periods of eccentricity or precession or to $\sim 30$ - and 50-k.y. periods. Also detected in our Fourier results are $\sim 30$ - and 50 -yr periodicities. These periods may be due to tonal resonance and interference, spectral aliasing, or perhaps to depositional cyclicity associated with the stratigraphic development of parasequence sets.

8. Although this margin has long been dominated by the development of shallow-water carbonates, the orbital forcing frequencies detected in these data likely stem from variations in terrigenous influx.

9. We conclude that from this high-resolution data set we are just beginning to resolve the link between sea-level changes deduced from sequence-stratigraphic analyses and those recognized from the oxygen isotope record. Better seismic resolution and temporal controls will be needed to refine these observations further.

\section{ACKNOWLEDGMENTS}

Financial support for this project was provided by a grant from the U.S. Scientific Advisory Committee (USSAC). We are grateful to Roy Wilkens for numerous discussions about Milankovitch rhythms and for his patience and help in analyzing the data via FFTs, and to Jack Kronen for fruitful discussions about depositional mechanisms and the response of seismic systems tracts. We also thank Kerry Kelts, John King, and Michael Arthur for reviews of the manuscript. To our colleagues and the ship and drilling crews of JOIDES Resolution we express our gratitude for their helpfulness and cooperation. This is UH SOEST Contribution No. 3158 .

\section{REFERENCES*}

Aharon, P., 1984. Implications of the coral-reef record from New Guinea concerning the astronomical theory of the ice ages. In Berger, A., Imbrie, J., Hays, J., Kukla, G., and Saltzman (Eds.), Milankovitch and Climate: Understanding the Response to Astronomical Forcing: Dordrecht (D. Reidel), 379-389.

Berger, A., Imbrie, J., Hays, J., Kukla, G., and Saltzman (Eds.), 1984. Milankovitch and Climate: Understanding the Response to Astronomical Forcing: Dordrecht (D. Reidel).

Berger, A.L., 1978. Long-term variations of caloric insolation resulting from earth's orbital variations. Quat. Res. (N.Y.), 9:139-167.

Berggren, W.A., Kent, D.V., and Van Couvering, J.A., 1985. The Neogene: Part 2. Neogene geochronology and chronostratigraphy. In Snelling, N.J. (Ed.), The Chronology of the Geological Record. Geol. Soc. London Mem., 10:211-260.

Bloemendal, J., and deMenocal, P., 1989. Evidence for a change in the periodicity of tropical climate cycles at $2.4 \mathrm{Myr}$ from whole-core magnetic susceptibility measurements. Nature, 342:897-900.

Bloemendal, J., Lamb, B., and King, J., 1988. Paleoenvironmental implications of rock-magnetic properties of late Quaternary sedi-ment cores from the eastern equatorial Atlantic. Paleoceanography, 3:61-87.

Boardman, M.R., Neumann, A.C., Baker, P.A., Dulin, L.A., Kenter, R.J., Hunter, G.E., and Keifer, K.B., 1986. Banktop response to Quaternary fluctuations in sea level recorded in periplatform sediments. Geology, 14:28-31.

Davies, P.J., Marshall, J.F., and Hopley, D., 1985. Relationships between reef growth and sea level rise in the Great Barrier Reef. Proc. 5th Int. Coral Reef Congr., Tahiti, 3:95-104.

Davis, J.C., 1986. Statistics and Data Analysis in Geology (2nd ed.): New York (Wiley).

Doh, S.-J., King, J.W., and Leinen, M., 1988. A rock-magnetic study of giant piston core LL44-GPC3 from the central North Pacific and its paleoceanographic implications. Paleoceanography, 3:89-111.

Droxler, A.W., and Schlager, W., 1985. Glacial versus interglacial sedimentation rates and turbidite frequency in the Bahamas. Geology, 13:799-802.

Einsele, G., Ricken, W., and Seilacher, A. (Eds.), 1991. Cycles and Events in Stratigraphy: Berlin (Springer-Verlag).

Engleman, E.E., Jackson, L.L., and Norton, D.R., 1985. Determination of carbonate carbon in geologic materials by coulometric titration. Chem. Geol., 53:125-128.

Enos, P., 1991. Sedimentary parameters for computer modeling. In Franseen, E.K., Watney, W.L., Kendall, C.G.St.C., and Ross, W. (Eds.), Sedimentary Modeling: Computer Simulations and Methods for Improved Parameter Definition. Kansas Geol. Surv. Bull., 233:63-99.

Fischer, A.G., and Bottjer, D.J., 1992. Orbital forcing and sedimentary sequences. J. Sediment. Petrol., 61:1063-1268.

Fulthrope, C.S., 1991. Geological controls on seismic sequence resolution. Geology, 19:61-65.

Glenn, C.R., and Kelts, K., 1991. Sedimentary rhythms in lake deposits. In Einsele, G., Ricken, W., and Seilacher, A. (Eds.), Cycles and Events in Stratigraphy: Berlin (Springer-Verlag), 188-221.

Hays, J.D., Imbrie, J., and Shackleton, N.J., 1976. Variations in the earth's orbit: pacemaker of the ice ages. Science, 194:1121-1132.

\footnotetext{
Abbreviations for names of organizations and publications in ODP reference lists follow the style given in Chemical Abstracts Service Source Index (published by American Chemical Society).
} 
Huffman, E.W.D., 1977. Performance of a new automatic carbon dioxide coulometer. Microchem. J., 22:567-573.

Imbrie, J., Hays, J.D., Martinson, D.G., McIntyre, A., Mix, A.C., Morley, J.J., Pisias, N.G., Prell, W.L., and Shackleton, N.J., 1984. The orbital theory of Pleistocene climate: support from a revised chronology of the marine delta $\delta^{18} \mathrm{O}$ record. In Berger, A., Imbrie, J., Hays, J., Kukla, G., and Saltzman, B. (Eds.), Milankovitch and Climate (Pt. 1): Dordrecht (D. Reidel), 269 -305.

Imbrie, J., McIntyre, A., and Mix, A., 1989. Oceanic response to orbital forcing in the late Quaternary: observational and experimental strategies. In Berger, A., Schneider, S., and Duplessy, J.C. (Eds.), Climate and Geo-Sciences: Dordrecht (Kluwer Academic), 121-164.

Jarrard, R.D., and Arthur, M.A., 1989. Milankovitch paleoceanographic cycles in geophysical logs from ODP Leg 105, Labrador Sea and Baffin Bay. In Srivastava, S.P., Arthur, M.A., Clement, B., et al., Proc. ODP, Sci. Results, 105: College Station, TX (Ocean Drilling Program), 757-772.

Jenkins, G.M., and Watts, D.G., 1968. Spectral Analysis and Its Applications: San Francisco (Holden Day).

Joyce, J.E., Tjalsma, L.R.C., and Prutzman, J.M., 1990. High-resolution planktic stable isotope record and spectral analysis for the last 5.35 M.Y.: Ocean Drilling Program Site 625 Northeast Gulf of Mexico. Paleoceanog. raphy, 5:507-529.

Kent, D.V., 1982. Apparent correlation of paleomagnetic intensity and climatic records in deep-sea sediments. Nature, 299:538-539.

Martinson, D.G., Menke, W., and Stoffa, P.L., 1982. An inverse approach to signal correlation. J. Geophys. Res., 87:4807-4818.

Martinson, D.G., Pisias, N.G., Hays, J.D., Imbrie, I., Moore, T.C., Jr., and Shackleton, N.J., 1987. Age dating and the orbital theory of the ice ages: development of a high-resolution 0 to 300,000 -year chronostratigraphy. Quat. Res. (N.Y.), 27:1-29.

Maxwell, W.G.H., 1968. Atlas of the Great Barrier Reef: London (Elsevier).

Mead, G.A., Tauxe, L., and LaBrecque, J.L., 1986. Oligocene paleoceanography of the South Atlantic: paleoclimatic implications of sediment accumulation rates and magnetic susceptibility. Paleoceanography, 1:273-284.

Pisias, N.G., and Mix, A.C., 1988. Aliasing of the geologic record and the search for long-period Milankovitch cycles. Paleoceanography, 3:613-619.

Pokras, E.M., and Mix, A.C., 1985. Eolian evidence for spacial variability of late Quaternary climates in tropical Africa. Quat. Res. (N.Y.), 24:137-149.

Prell, W.L., 1982. Oxygen and carbon isotope stratigraphy for the Quaternary of Hole 502B: evidence for two modes of isotopic variability. In Prell, W.L., Gardner, J.V., et al., Init. Repts. DSDP, 68: Washington (U.S. Govt. Printing Office), $455-464$.

Prell, W.L., and Kutzbach, J.E., 1987. Monsoon variability over the past 150,000 years. J. Geophys. Res., 92:8411-8425.

Prell, W.L., and Van Campo, E., 1986. Coherent response of Arabian Sea upwelling and pollen transport to late Quaternary monsoonal winds. $\mathrm{Na}$ ture, 323:526-528.

Reynolds, D.J., Steckler, M.S., and Coakley, B.J., 1991. The role of sediment load in sequence stratigraphy: the influence of flexural isostasy and compaction. J. Geophys. Res., 96:6931-6949.
Robinson, S.G., 1986. The late Pleistocene paleoclimatic record of North Atlantic deep-sea sediments revealed by mineral-magnetic measurements. Phys. Earth Planet. Inter, 42:22-47.

Roof, S.R., Mullins, H.T., Gartner, S., Huang, T.C., Joyce, E., Prutzman, J., and Tjalsma, L., 1991. Climatic forcing of cyclic carbonate sedimentation during the last 5.4 million years along the west Florida continental margin. J. Sediment. Petrol., 61:1070-1088.

Rossignol-Strick, M., 1983. African monsoons: an immediate climate response to orbital insolation. Nature, 303:46-49.

Ruddiman, W.F., Raymo, M.E., Martinson, D.G., Clement, B.M., and Backman, J., 1989. Pleistocene evolution: Northern Hemisphere ice sheets and North Atlantic Ocean. Paleoceanography, 4:353-412.

Shackleton, N.J., Berger, A., and Peltier, W.R., 1990. An alternative astronomical calibration of the lower Pleistocene timescale based on ODP Site 677. Trans. R. Soc. Edinburgh, Earth Sci., 81:251-261.

Shackleton, N.J., and Opdyke, N.D., 1976. Oxygen-isotope and paleomagnetic stratigraphy of Pacific Core V28-239: late Pliocene to latest Pleistocene. In Cline, R.M., and Hays, J.D. (Eds.), Investigations of Late Quaternary Paleoceanography and Paleoclimatology. Mem.-Geol. Soc. Am., 145:449-464.

Shipboard Scientific Party, 1991. Site 821. In Davies, P.J., McKenzie, J.A., Palmer-Julson, A., et al., Proc. ODP, Init. Repts., 133 (Pt. 1): College Station, TX (Ocean Drilling Program), 569-614.

Short, D.A., and Mengel, J.G., 1986. Tropical climatic phase lags and the Earth's precessional system. Nature, 323:48-50.

Symonds, P.A., Davies, P.J., and Parisi, A., 1983. Structure and stratigraphy of the central Great Barrier Reef. BMR J. Aust. Geol. Geophys., 8:277-291,

Vail, P.R., Audemard, F., Bowman, S.A., Eisner, P.N., and Perez-Cruz,C., 1991. The stratigraphic signatures of tectonics, eustasy and sedimentology - an overview. In Einsele, G., Ricken, W., and Seilacher, A. (Eds.), Cycles and Events in Stratigraphy: Berlin (Springer-Verlag), 617-659.

Van Wagoner, J.C., Mitchum, R.M., Campion, K.M., and Rahmanian, V.D., 1990. Siliciclastic Sequence Stratigraphy in Well Logs, Cores, and Outcrops: Concepts for High-Resolution Correlation of Time and Facies. AAPG, Methods Explor. Ser., 7.

Williams, D.F., Thunell, R.C., Tappa, E., Rio, D., and Raffi, I., 1988. Chronology of the Pleistocene oxygen-isotope record: 0-1.88 m.y.B.P. Palaeogeogr., Palaeoclimatol., Palaeoecol., 64:221-240.

Wornardt, W.W., and Vail, P.R., 1991. Tentative revision of the global Pliocene-Pleistocene Sequences based on sequence stratigraphy in the Gulf of Mexico. AAPG Bull., 75:1425

Date of initial receipt: 24 April 1992

Date of acceptance: 17 December 1992

Ms 133SR-240 